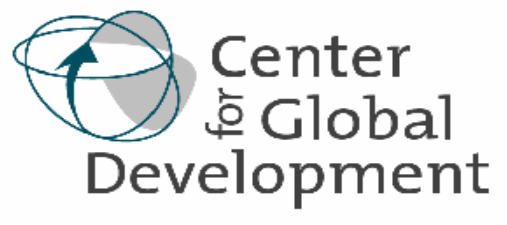

\title{
Why Doesn't Africa Get More Equity Investment? Frontier Stock Markets, Firm Size and Asset Allocations of Global Emerging Market Funds By Todd Moss, Vijaya Ramachandran and Scott Standley
}

\begin{abstract}
This paper addresses the question of investment in sub-Saharan African listed securities by examining characteristics of the continent's 15 equity markets, the rise and fall of African regional funds, and the asset allocation trends for global emerging market (GEM) funds. The data shows that South Africa is now a leading destination of capital, but that few managers invest elsewhere on the continent. However, we find that African markets are not treated differently than other markets and present evidence that small market size and low levels of liquidity are a binding deterrent for foreign institutional investors. Thus, orthodox market variables rather than market failure appear to explain Africa's low absolute levels of inward equity flows. The paper then turns to new data from firm surveys to explore why African firms remain small. The implications of our findings are threefold: (a) efforts to encourage greater private investment in these markets should concentrate on domestic audiences and specialized regional funds, (b) the depth and success of the Johannesburg Stock Exchange can perhaps be better utilized to benefit other parts of the continent, and (c) any long-term strategy should concentrate on the underlying barriers to firm entry and growth.
\end{abstract}

The Center for Global Development is an independent think tank that works to reduce global poverty and inequality through rigorous research and active engagement with the policy community. Use and dissemination of this Working Paper is encouraged, however reproduced copies may not be used for commercial purposes. Further usage is permitted under the terms of the Creative Commons License. The views expressed in this paper are those of the author and should not be attributed to the directors or funders of the Center for Global Development. The authors are grateful for funding from the World Bank.

www.cgdev.org 


\title{
Why Doesn't Africa Get More Equity Investment? Frontier Stock Markets, Firm Size, and Asset Allocations of Global Emerging Market Funds
}

\author{
Todd Moss, Vijaya Ramachandran, and Scott Standley ${ }^{1}$
}

\section{Introduction}

The rapid integration of international financial markets has been one of the starkest examples of globalization. The impressive rise of private capital flows to emerging markets, from $\$ 25$ billion in 1990 to $\$ 300$ billion in 2005, has been a key feature of this trend. Part of this expansion in financial flows has been enabled by the growth of equity funds dedicated to investing in publicly-listed securities in developing countries. ${ }^{2}$ The number of emerging market funds grew from just a handful at the beginning of the 1990s to over 100 by the end of that decade (Kaminsky, Lyons, and Schmukler 2001). ${ }^{3}$ Sub-Saharan Africa has also participated in this trend, with South Africa rising into the ranks of the leading destination emerging markets and a number of regional funds specifically targeting the continent. At the behest of local governments, and with some donor encouragement, Africa has also expanded the number of its domestic stock exchanges from five in the late 1980s to fifteen today. Despite this modest headway, Africa's "frontier markets" - those outside South Africa-still receive a tiny fraction of emerging markets investment and the widespread reaction in Africa has been of disappointment. Policymakers in both African and donor capitals have fretted about this lack of response by private investors and frequently ask: why is Africa not receiving more equity investment?

There are two schools of thought. The first "market failure" view is that Africa is somehow different and investors are not responding rationally to the continent's investment opportunities because of some hurdle: a lack of information, perceptions of excessive risk, or another, perhaps unknown, variable that systematically discourages investors from bringing their capital into Africa. A second "market works" view argues that there is nothing unusual or exotic about

\footnotetext{
${ }^{1}$ Todd Moss (tmoss@cgdev.org) is Senior Fellow at the Center for Global Development. Vijaya Ramachandran (vr9@georgetown.edu) is Assistant Professor at the Georgeown Public Policy Institute and Visiting Fellow at CGD. Scott Standley (sstandley@imf.org) was a researcher at CGD when this paper was completed and is currently a Research Officer in the Independent Evaluation Office of the IMF. The authors thank the World Bank for funding this work. We thank Jenni Chamberlain, Ryan Floyd, Alan Gelb, Liliana Rojas-Suarez, John Simon, and Tom Gibian for comments, as well as participants at the African Economic Research Consortium workshop in Nairobi on and participants at a seminar at the World Bank in Washington DC. We are also grateful to Sarah Rose for research assistance. All errors and opinions expressed in this paper are solely those of its authors and do not necessarily reflect the views of affiliated institutions or national authorities.

${ }^{2}$ This paper deals only with funds targeting listed securities publicly traded on local stock markets, and explicitly does not cover either private equity or foreign direct investment (FDI). The universe of private equity funds, venture capital, and other asset classes are areas of future research for CGD. FDI is also beyond this paper. Recent data suggests FDI grown considerably in recent years, and not only to mineral/oil exporters.

${ }^{3}$ See also Lavelle 1999 on the role of the international financial institutions in helping to launch new closed-end funds.
} 
Africa and that investors value African investments like any other. If they are avoiding the continent it is likely because of orthodox reasons such as liquidity or market size.

This paper seeks to answer this question by looking at the characteristics of African equity markets and the activities of the two primary groups of foreign institutional investors: regional funds (which, by definition, invest in companies listed on African stock markets) and global emerging market funds (which, by definition, invest in developing countries but not necessarily any particular geographic region). A scan of the 94 global emerging market funds for which we have data shows that they all invest in South Africa, but almost none invest elsewhere on the continent. But we also find that African markets are not fundamentally different from those in other regions given their relative size. After correlating market and country data with the asset allocation of these funds, we find that African markets are not treated differently than other markets, which suggests that a primary deterrent for foreign institutional investors is the small size and low levels of liquidity for available shares. That is, for the GEM asset class, the evidence points strongly in the direction of a "market works" view and that Africa's market "problem" is mostly one of size.

The implication of our findings is that, at least in the near to medium term, African equity markets are likely to remain targeted primarily by highly-specialized niche funds with specific mandates to invest in the region. Those that seek to encourage greater private investment in these markets should focus their efforts on this handful of foreign players and, probably more importantly, domestic institutional and individual investors. A strategy for longer-term growth of these markets should concentrate on the underlying factors preventing market expansion, namely the barriers to firm entry and growth that would allow more and larger firms - which could potentially list on local exchanges and be exposed to a greater number of potential investors. Surely, Africa's frontier equity markets can play a more prominent role in their host economies, but it is not yet clear that they are unusually underperforming given their environments. The current emphasis on fixing perceived market failures is not only attempting to tackle a problem that may in fact not exist, but is diverting policymakers' attention away from the real economic constraints. Interventions to boost equity investments based on fixing the "market failure" are thus akin to attacking the symptoms rather than the cause.

Section 2 of this paper frames why these questions about equity investment are important for economic development, how they fit into current academic debates, and how they might affect the range of options facing policymakers seeking to encourage greater flows to the poorest regions. Section 3 looks specifically at Africa's equity markets and some of the dominant characteristics, including how these markets compare with those in other regions. Section 4 documents the rise and fall (and perhaps rise again) of regional funds. Section 5 analyses the asset allocation of global emerging market funds, concluding that African firms and markets are too small to attract much attention from this particular asset class of investors. Section 6 looks at why African firms remain small using data from firm surveys on the barriers to firm growth in Africa. Section 7 concludes with implications for policymakers. 


\section{Why is equity investment relevant to development?}

Questions about stock market characteristics and equity investment flows to Africa are directly relevant to the development community in at least three ways. At the broadest level, there are thought to be strong links between the financial sector and economic growth. Schumpeter (1934) was an early proponent of the idea that finance was important for economic development, claiming that the system for allocating capital has a substantial impact on economic growth. (Others, such as Robinson (1952), questioned the direction of causality, suggesting that perhaps capital chased growth rather than the other way around.) In the seminal works on finance in developing countries, McKinnon (1973) and Shaw (1973) interpreted evidence from a number of emerging economies as strongly suggesting that Schumpeter was largely correct and that financial systems facilitated economic growth. More recent empirical research by King and Levine (1993) suggests a strong correlation between financial development and economic growth, while Caprio and Demirguc-Kunt (1997) found that higher levels of long term finance were associated with higher productivity and growth. Research by Levine and Zervos (1996) suggests that stock markets themselves are correlated with improved economic performance.

There are multiple ways in which capital markets might be expected to have such an impact on development: to serve as a source of long-term capital for financing investment, to expand the menu of financial instruments available to savers (allowing risk diversification and encouraging resource mobilization), and to continuously monitor the corporate sector. In addition, deep financial systems facilitate the trading of risk, allocate capital, monitor managers, mobilize savings, and ease the exchange of goods, services, and financial contracts (Levine 1996). There is even some evidence that institutional investors in particular (as opposed to individuals or smallholders) have an especially positive impact on corporate governance (Samuel 1996). While foreign private capital flows are increasingly viewed as playing these roles in emerging markets - with private capital displacing official flows for many countries - this trend is just barely beginning in Africa’s frontier markets (Ndikumana 2001; Kenny and Moss 1998).

This paper also contributes to the ongoing debates about the factors behind capital flow trends. The literature on the determinants of capital flows to emerging markets frequently differentiates between the global ("push”) factors and the local ("pull”) factors. The most significant push factors tend to be interest rates in industrialized countries and investor diversification (Chuhan, Claessens and Mamingi, 1993; Fernandez-Arias and Montiel, 1996; Frankel and Okongwu, 1995; Fernandez-Arias, 1994). The major pull factors are related to the strength of an economy, the profitability of its firms, and a country's perceived policy and risk environment (Offerdal, 1996; Bhattacharya, Montiel and Sharma, 1996). In general, the consensus view is that push factors help to influence the overall appetite for emerging markets among investors, but that pull factors are crucial in determining where precisely those flows are placed-a conclusion that is consistent with our findings.

Lastly, and more immediately, this paper aims to help inform policymakers both in African and in donor capitals as they consider, devise, and implement strategies to catalyze private investment. Substantial efforts are underway to try to encourage greater investment in subSaharan Africa: policy reforms, publicly-backed equity funds, subsidies for promotion activities, and technical assistance, among many such interventions thought to compensate for some failure in the marketplace. However, if the constraints to higher flows and the decision-making process 
of fund managers are not well understood, then the various interventions may be mis-targeted. Resources and actions by African officials and donors therefore might attack the wrong (or nonexistent) market failure and divert attention from the real constraints. The paper argues that, as regards global emerging market funds and their treatment of Africa, there is no apparent market failure. The best course of action may therefore lie outside the financial sector itself, within a set of policy reforms that improve the investment climate and increase the ability of private firms to survive and grow in a sustainable manner.

\section{Profile of Africa's equity markets}

Sub-Saharan Africa currently has 15 active stock exchanges (Table 1; see Moss 2003 for more background). South Africa's Johannesburg Stock Exchange (JSE) is the dominant market on the continent. At the end of 2005 the JSE was the $16^{\text {th }}$ largest exchange in world and is considered a sophisticated international market on par with the other leading emerging markets, such as Brazil or Malaysia. With a market capitalization of $\$ 566$ billion, the JSE accounts for $94 \%$ of subSaharan Africa's total and is more than 14 times larger than the all of the other markets combined.

Table 1: African Stock Exchanges, end-2005

\begin{tabular}{|lllll|}
\hline & $\begin{array}{l}\text { Number of listings } \\
\text { (incl. foreign) }\end{array}$ & $\begin{array}{l}\text { Market } \\
\text { capitalization } \\
\text { (US\$ bn) }\end{array}$ & $\begin{array}{l}\text { Value traded } \\
\text { (US\$ } \mathbf{~ m ) ~}\end{array}$ & $\begin{array}{l}\text { Return } \\
\text { (local index; \% in } \\
\text { US\$ terms) }\end{array}$ \\
\hline Botswana & 28 & 2.4 & 47 & -4.7 \\
Cote d'Ivoire (BRVM) & 39 & 2.6 & $47^{\mathrm{a}}$ & 26.0 \\
Ghana & 30 & 1.3 & 50 & -30.5 \\
Kenya & 48 & 6.4 & 484 & 46.4 \\
Malawi & 10 & 0.2 & 8 & 42.2 \\
Mauritius & 38 & 2.6 & 155 & 4.5 \\
Mozambique & 2 & 0.3 & na & na \\
Namibia & 28 & 0.4 & 529 & -3.6 \\
Nigeria & 214 & 19.4 & 1,917 & 2.3 \\
South Africa & 388 & 565.9 & 200,935 & 27.8 \\
Swaziland & 6 & 0.2 & $<1^{\mathbf{a}}$ & -11.0 \\
Tanzania & 8 & 0.5 & 14 & -12.2 \\
Uganda & 7 & 0.1 & 2 & -9.2 \\
Zambia & 14 & 0.9 & 13 & 125.3 \\
Zimbabwe & 79 & 1.9 & 385 & 14.1 \\
\hline Sub-Saharan Total & $\mathbf{9 3 9}$ & $\mathbf{6 0 5 . 1}$ & $\mathbf{2 0 4 , 5 8 6}$ & \\
ex South Africa & $\mathbf{5 5 1}$ & $\mathbf{3 9 . 2}$ & $\mathbf{3 , 6 5 1}$ & \\
\hline
\end{tabular}

${ }^{a} 2004$ data for Cote d'Ivoire and Swaziland. 'Uses estimate of parallel FX rate of Z\$100,000:US\$1. Sources: Standard Bank; Databank; African Business Research Limited; Standard \& Poor's (2005). 
Table 1 shows that markets are not just small but also relatively illiquid. South Africa's turnover ratio (traded value/market capitalization) is approximately 40 percent whereas for the smaller exchanges, the ratio is much smaller-Nigeria is about 10 percent, Kenya 8 percent and many of the others closer to 2 percent. This is reflected in the slope of the line in Figure 1 (the right graph) - log market capitalization of 6 corresponds to a traded value log of only 2.5 whereas log market capitalization of 14 corresponds to log traded value of almost 14.

While there are disparities among the other 14 "frontier markets," they are all still relatively small and underdeveloped. Five of the exchanges list 10 or fewer companies and all but Nigeria and Zimbabwe list less than 50. Meanwhile, 12 out of the 14 frontier exchanges have total market capitalizations under $\$ 3$ billion. While these are extremely small in comparison to developed or even mid-sized emerging markets, they are not out of line with global norms given the size of their host economies. The left graph of Figure 1 shows market capitalization vs GDP (in logs) for 80 economies considered by Standard \& Poor's to be “emerging markets," with the included African markets labeled.

\section{Figure 1: Market Size of Emerging Stock Markets 2004}
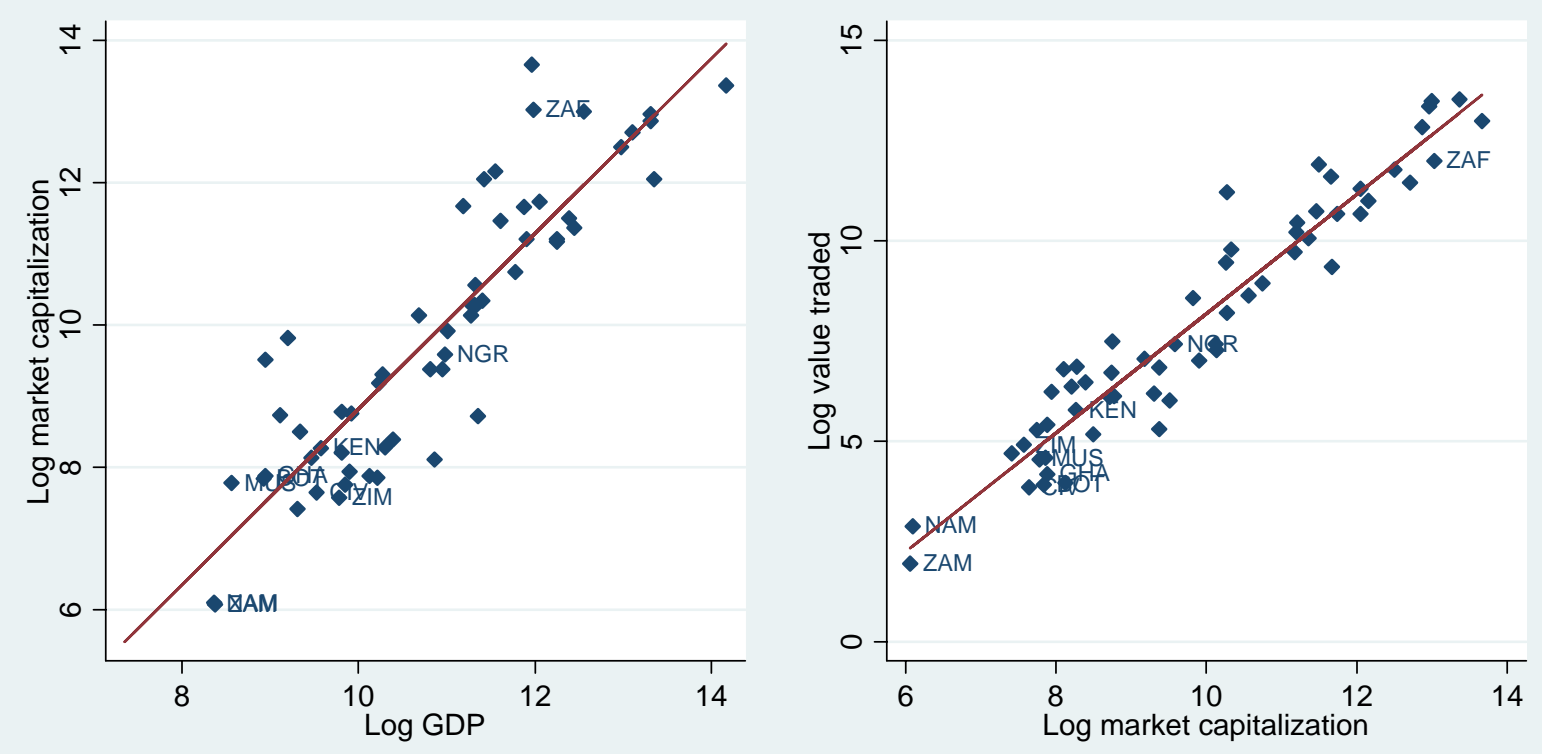

Note: Malawi and Mozambique are not included. GDP is 2003 data.

Sources: World Bank, World Development Indicators (2005) and Standard \& Poor’s (2005)

The data on dollar value of equities traded on African exchanges tell a similar story. At first glance Africa seems far behind. As one active regional fund manager put it, "an entire year's worth of trading in the frontier African markets is done before lunch on the New York Stock Exchange." 4 Indeed, global stock exchanges traded an average of \$150 billion per day in 2004, yet the combined trade for all 14 frontier markets in that entire year was just $\$ 2.4$ billion. South Africa traded \$201 billion and Nigeria \$1.9 billion in 2005, but nine African markets had \$50

\footnotetext{
${ }^{4}$ Emerging Market Management’s John Niepold, quoted in Christy (1998).
} 
million or less in trading activity for the entire year, and six had less than \$15 million. Even though these are very small absolute amounts-especially compared with the $\$ 43$ billion traded in Mexico or $\$ 639$ billion in South Korea that same year-they are consistent with global trends based on market size (Figure 1, right graph). Again, Africa’s frontier markets are undersized in absolute terms, but are not outliers given their relative size.

In addition to the market-wide annual trading data, we also have a unique window into trading in Africa's frontier markets through information provided by Securities Africa, an advisory firm that works with nearly all the major institutional players in Africa. Because of low liquidity and a dearth of large blocks, these markets often act in practice more like private equity with advisors/brokers actively putting together most institutional-sized deals. Table 2 shows a snapshot of the available blocks on offer at a particular recent point in time. Consistent with the annual data showing low overall trading sizes, this table shows the very small number of large blocks available for trading: across all the frontier markets, there were only 3 bids and 2 offers for blocks greater than $\$ 5$ million, and only 14 bids and 8 offers greater than $\$ 1$ million. In addition, of the 85 total blocks (both bids and offers) available to the marketplace, more than half are less than $\$ 500,000$. As we will see below, this shortage of sizeable blocks of shares excludes a priori many funds which have minimum trade sizes that cannot be met by this kind of trading activity. 
Table 2: Available blocks of African shares, October 2006

\begin{tabular}{llllll} 
& \multicolumn{1}{c}{ Total } & $>\$ 5,000,000$ & $>\$ 1,000,000$ & $>\$ 500,000$ \\
\hline Botswana & & & & & \\
& Bid & 5 & 0 & 3 & 4 \\
Cote d'Ivoire & Offer & 2 & 0 & 0 & 1 \\
& & & & 1 & 2 \\
& Bid & 3 & 1 & 0 & 0
\end{tabular}

Ghana

$\begin{array}{lllll}\text { Bid } & 7 & 0 & 0 & 0 \\ \text { Offer } & 6 & 0 & 0 & 0\end{array}$

Kenya

$\begin{array}{lllll}\text { Bid } & 4 & 0 & 2 & 2 \\ \text { Offer } & 3 & 0 & 1 & 2\end{array}$

Malawi

$\begin{array}{lllll}\text { Bid } & 2 & 0 & 1 & 1 \\ \text { Offer } & 4 & 0 & 0 & 1\end{array}$

Mauritius

$\begin{array}{lllll}\text { Bid } & 0 & 0 & 0 & 0 \\ \text { Offer } & 2 & 0 & 0 & 0\end{array}$

Namibia

$\begin{array}{lllll}\text { Bid } & 4 & 0 & 0 & 0 \\ \text { Offer } & 1 & 0 & 0 & 0\end{array}$

Nigeria

$\begin{array}{lllll}\text { Bid } & 4 & 2 & 4 & 4 \\ \text { Offer } & 4 & 1 & 3 & 3\end{array}$

Uganda

$\begin{array}{lllll}\text { Bid } & 1 & 0 & 0 & 0 \\ \text { Offer } & 0 & 0 & 0 & 0\end{array}$

Zambia

$\begin{array}{lllll}\text { Bid } & 15 & 0 & 0 & 4 \\ \text { Offer } & 7 & 1 & 3 & 3\end{array}$

Zimbabwe

$\begin{array}{lllll}\text { Bid } & 4 & 0 & 3 & 3 \\ \text { Offer } & 2 & 0 & 1 & 2\end{array}$

Note: All data is from October 9, 2006, using market price from Securities Africa, Africanfinancialmarkets.com or directly from individual bourses. Exchange rates are from FT.com

Source: Securities Africa 


\section{Foreign institutional investors: Africa regional funds}

In addition to their own domestic investors, emerging markets seeking to grow tend to have two natural investment fund types that they target: regional or country-specific funds and general emerging market funds. ${ }^{5}$

Africa's regional funds have been highly volatile. Prior to the mid-1990s, there was only the longstanding UBS Equity Fund South Africa. Around 1994-95, a result of renewed interest in South Africa after its first democratic elections and a general boom in emerging markets, more than a dozen new Africa-specific regional equity funds were launched, most with great enthusiasm and considerable press coverage. The funds were marketed as an efficient way to diversify since African markets tend to be less correlated with the major developed country exchanges and also as a chance to get in early while valuations were still low relative to other emerging markets (Siddiqi 1997). Reflecting the mood at the time and the hopes that Africa was at the beginning of its own investment boom, one manager of the Calvert New Africa Fund claimed that "Africa is approximately at the same stage where markets in Asia and Latin America were 15 years ago." 6 At the launch of the Calvert Fund, the South African ambassador to the US predicted that the fund's name "will be written in the history of Africa” (Sisler 1995). (As we will see below, Calvert did gain notoriety, but not for the reasons the ambassador hoped.)

Though the Africa regional funds varied in size and specific geographic focus, most were small and fairly modest in scope by global standards (Table 3). The largest was the Morgan Stanley Africa Investment Fund, worth about \$260 million at its launch in 1994 and at its height had estimated assets over \$300 million. The Morgan Stanley fund had a pan-African focus with investments in at least 12 African countries. According to co-manager Michael Schwabe, "we have a mandate to provide pan-African exposure, and so we offer access to markets that are difficult to access any other way” (Emergingportfolio.com 1999). But Morgan Stanley was not representative of the typical African equity fund, most of which were considerably more modest. For example, Barings Simba Fund—also highly touted in the press—was only about \$30 million in total capitalization.

\footnotetext{
${ }^{5}$ There are of course other fund types that might be interested in publicly-listed African securities, such as Middle East/Africa funds (e.g., Arisaig or Imara) or specific frontier funds (e.g., Terra Partners Worldwide Opportunity Fund, Ondine Frontier Market Select Fund) but these tend to be very small and difficult to track.

${ }^{6}$ Justin Beckett of the Calvert New Africa Fund, quoted in Sisler (1995).
} 


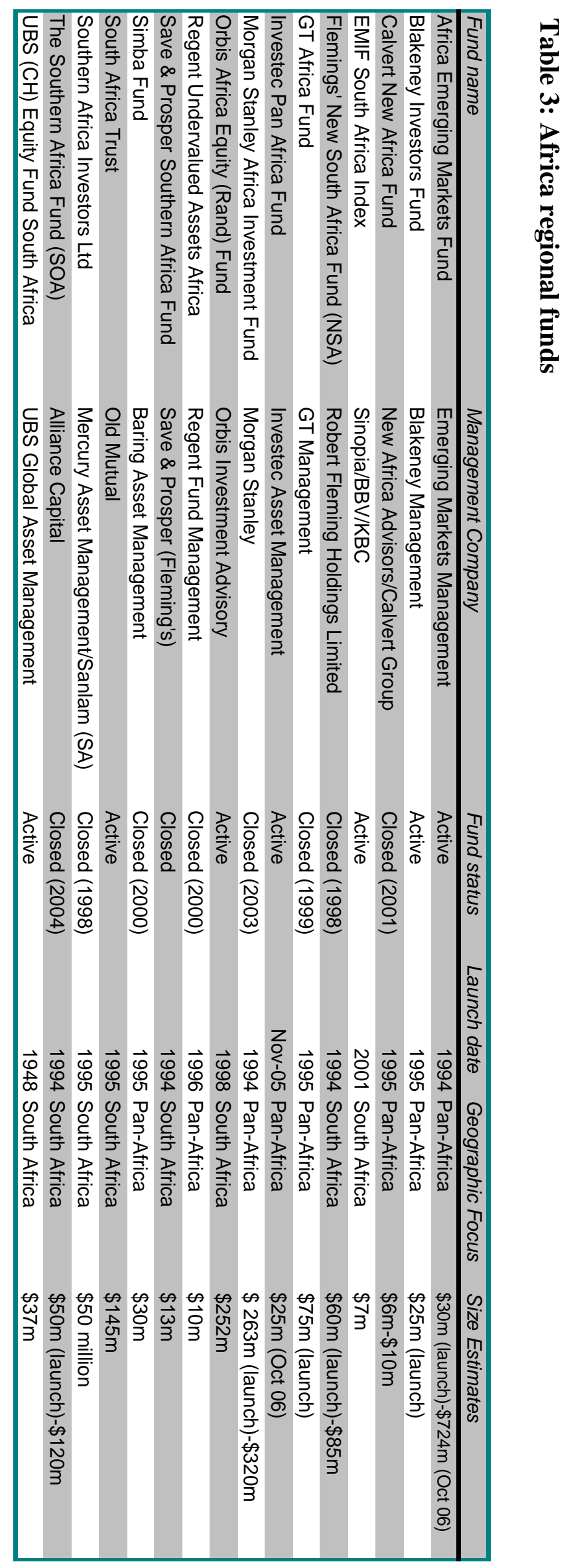


Much of this initial enthusiasm for Africa funds was short-lived. The vast majority have since closed owing to poor returns, lack of investor interest, or, in at least one case, mismanagement. By 2006 only around seven of the funds remain active (Figure 2). Of these, only two are PanAfrican survivors from the mid-1990s (the African Emerging Markets Fund and the Blakeney Investors Fund) and four invest only in South Africa. The remaining one, Investec's Pan Africa Fund, was launched only in November 2005 (see below). ${ }^{7}$

\section{Figure 2: Africa regional funds}

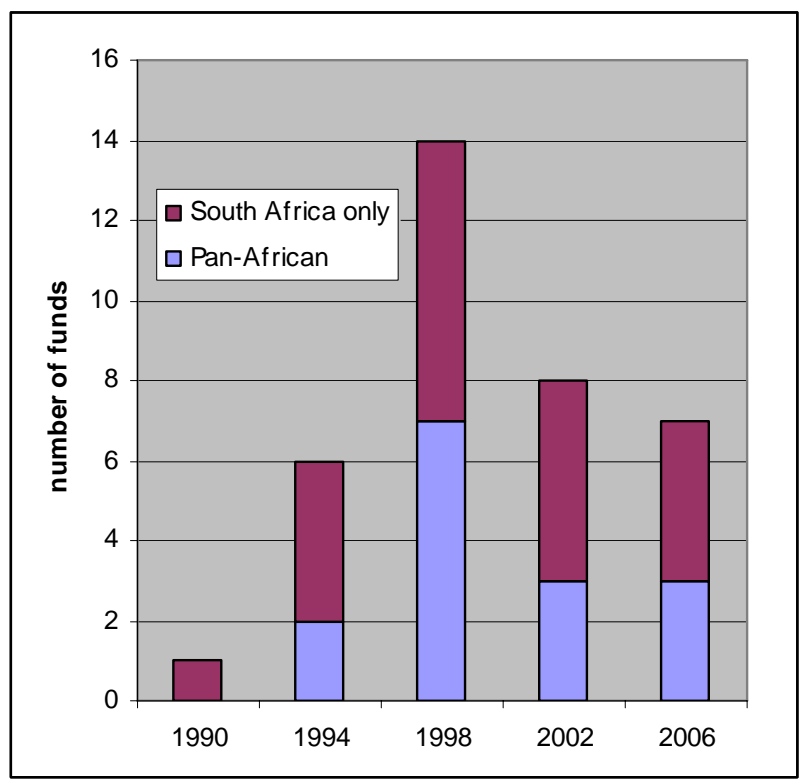

The first wave of Africa funds generally performed poorly and had difficulty attracting investors. Full details of why so many of these funds failed are not available, but press reports and some fund documentation can give the outlines of a few illustrative stories:

- The Morgan Stanley Africa Fund was a closed-end fund listed on the New York Stock Exchange and also began with a commitment to markets beyond South Africa, with initial plans to maintain South Africa's allocation at only 30-40\% with the remainder of the portfolio spread throughout the continent, most heavily in Egypt, Ghana, and Mauritius. But the fund did not perform; by the beginning of 2002, when the decision was made to begin liquidation, it had lost an average of $6 \%$ per year over the previous five years. It was also unable to find enough investments in the frontier markets; by the time of liquidation, 84\% of the fund was invested in South Africa (Morgan Stanley 2001).

- The Calvert New Africa Fund was launched in April 1995, hailed by its managers as the first mutual fund aimed at attracting American investors to African markets. Unlike most

\footnotetext{
${ }^{7}$ There are several new funds reportedly just getting started (e.g, the Bermuda-based Finch Africa Fund) and others under consideration. In parallel to the rise and fall of funds has been niche media outlets. A number of newsletters and other services aimed at encouraging private investment in African equity markets arose in the mid 1990s, most of which quickly closed. However, there may be an uptick in these again as well; one example is investinginafrica.net which launched in early 2006.
} 
of the other funds, Calvert targeted individual investors rather than institutions. The fund, split between New Africa Advisors (NAA) and Calvert, planned to initially invest $85 \%$ in South Africa but expected to expand into other markets including Ghana and Zimbabwe (Umoren 1995). The fund quickly ran into performance and management difficulties. After losing 19\% in 1999 and 33\% in 2000, the fund was also hit with a scandal at NAA. ${ }^{8}$ Calvert folded the remaining assets into a small South Africa Fund (EIU 2001) A year later - without publicity - this was merged into a larger International Equity Fund, citing "poor performance and problems attracting sufficient assets" (Murray 2002). The International Fund currently invests only around 2\% in South Africa and none in the frontier markets. ${ }^{9}$

- The Barings Simba Fund generally underperformed since its launch and was never able to generate momentum. The final performance statement in 2000 claimed that net asset value per share fell 14\% during the first six months of 2000 (Simba Fund Ltd. 2000) and the fund finally went into liquidation in September of that year.

- Regent Undervalued Assets Africa also failed. The fund was aggressively frontierfocused; its South African exposure was targeted at just $16 \%$ of the portfolio at launch (Economist 1997), but lost 31\% in its first six months (Africa Financing Review 1998). In 2000 the fund was de-listed from its exchanges in Dublin, Nairobi, and Gaborone and eventually liquidated and dissolved.

- EMM's Africa Emerging Markets Fund stands as the most notable exception to the trail of poor-performance, no doubt one reason it is one of the only originals from the mid1990s left. According to Standard \& Poor's, the fund gained an average of $20.4 \%$ annually over the past ten years, and $61 \%$ per year during the last three years (S\&P 2006). As a result, its assets have grown from $\$ 30$ million at launch in 1994 to $\$ 724$ million by October 2006 (ibid). EMM currently invests throughout the continent, with exposure in ten countries: Botswana, Cote d'Ivoire, Ghana, Kenya, Nigeria, Mauritius, Namibia, Zambia, Senegal and Mali (the last two presumably through listed shares in Abidjan and Accra, respectively, since they have no stock markets of their own).

Despite the generally disappointing track record of African regional equity funds, there are signs that interest in the region may be reviving, and that new regional equity funds may emerge. Investec, a major South African financial services group, announced in 2005 the start of two new Africa funds, one pan-Africa fund targeting foreign investors and the other targeting South African institutions looking to invest in the region. The former, the Investec Pan Africa Fund,

\footnotetext{
${ }^{8}$ In November 2000 NAA's fund manager Justin Beckett was accused of fraud and asked to resign from his position as head of another NAA-managed fund, the New Africa Opportunity Fund, a private equity fund launched in 1996 and backed by the Overseas Private Investment Corporation (OPIC), a US government agency. According to later court documents, Beckett was accused of ignoring fund guidelines, misappropriating, and falsifying documents. See Sloan Financial Group, Inc., et al. v. Justin F. Beckett 2003. The controversy also unsurprisingly led to the dismissal of NAA from its role as advisor to the Calvert New Africa Fund. See Serres 2001. Beckett is now CEO of Fluid Audio Networks, which runs the American Idol Underground website.

${ }^{9}$ This type of merger is common with failing funds. In order "to avoid closing funds, companies often merge sagging funds into other funds within the same family." See Justin Wiser, "Record 225 mutual funds close in 2000,” CBSMarketWatch.com, April 9, 2001.
} 
has in its first year since launch raised \$25 million and invested in ten countries (Investec 2006). Only 34\% of the portfolio is in South Africa, and it plans to limit its South African holdings to $50 \%$ or under (Cranston 2005).

Africa's regional funds have thus been both highly specialized and extremely volatile. Most of the funds that appeared in the heady emerging market days of the mid-1990s are now gone, but the very few that have shown positive returns have survived and grown. Whether Investec's new fund is an anomaly or the beginning of a trend of expanded interest, it is too early to say. Nevertheless, because of their specific geographic focus, regional funds are likely to be the dominant foreign fund players in the region. They thus hold potential for generating new inflows and for boosting trading volume in the frontier markets for the medium term.

\section{Foreign institutional investors: Global emerging market funds}

The other type of equity funds that might a priori be interested in African markets are global emerging market (GEM) funds, which have a mandate to invest their portfolios in across a range of emerging markets but do not have a specific geographic focus. If African markets are hoping to attract foreign capital, it might be expected that they would complement the small (and often quirky) boutique regional funds and begin to tap the very large pool of GEM money searching for undiscovered assets in developing countries.

To investigate the activities of GEM funds, we use a dataset from EmergingPortfolio.com Fund Research (EPFR). ${ }^{10}$ The data includes end-year asset allocation by country for a large sample of GEM funds from 1995-2005, which, according to EPFR, covers 80-90\% of the total GEM universe. ${ }^{11}$ EPFR includes 11 African equity markets in its coverage: Botswana, Ghana, Cote d’Ivoire, Kenya, Malawi, Mauritius, Namibia, Nigeria, South Africa, Zambia and Zimbabwe. (While Uganda, Tanzania, Swaziland and Mozambique are not included in the EPFR dataset, these four markets are among Africa's smallest and their exclusion is unlikely to affect the results). For end-2005, the data include information on 94 funds with total assets under management of $\$ 95$ billion. Overall, the bulk of GEM holdings, 55\% of the total, are in Asia, while holdings in sub-Saharan Africa are valued at $\$ 9.4$ billion, or $10 \%$ of the total (see Annex B; Table B1). But two striking facts immediately surface from this data: (a) every fund in the sample has at least one holding in South Africa and (b) a scant \$28 million is held in Africa's frontier markets.

Worldwide, South Africa is now the fourth largest destination of GEM investment, trailing only Korea, Taiwan, and Brazil, and ahead of Mexico, India, and China (Annex B; Table B2). Additionally, GEM investment to South Africa has also grown considerably over time, both in absolute terms and as a share of the global total (Figure 3 for moving 3-year averages). Since 1995, South Africa's share of worldwide GEM investment has more than doubled, while its absolute holdings have risen from under \$1.5 billion a decade ago to \$9.4 billion held in 2005 .

\footnotetext{
${ }^{10}$ Other studies that have used EPFR dataset include, among others, Gelos and Wei (2002), Borensztein and Gelos (2000), Gottschalk and Griffith-Jones (2003) and Gande and Parseley (2004).

${ }^{11}$ Given the volatility and fluidity of the funds in this asset class, the funds are not all the same over the panel. The sample includes 107 funds in 1995 and 94 funds in 2005.
} 
Figure 3: GEM holdings in Africa 1996-2004

(3 year moving averages)

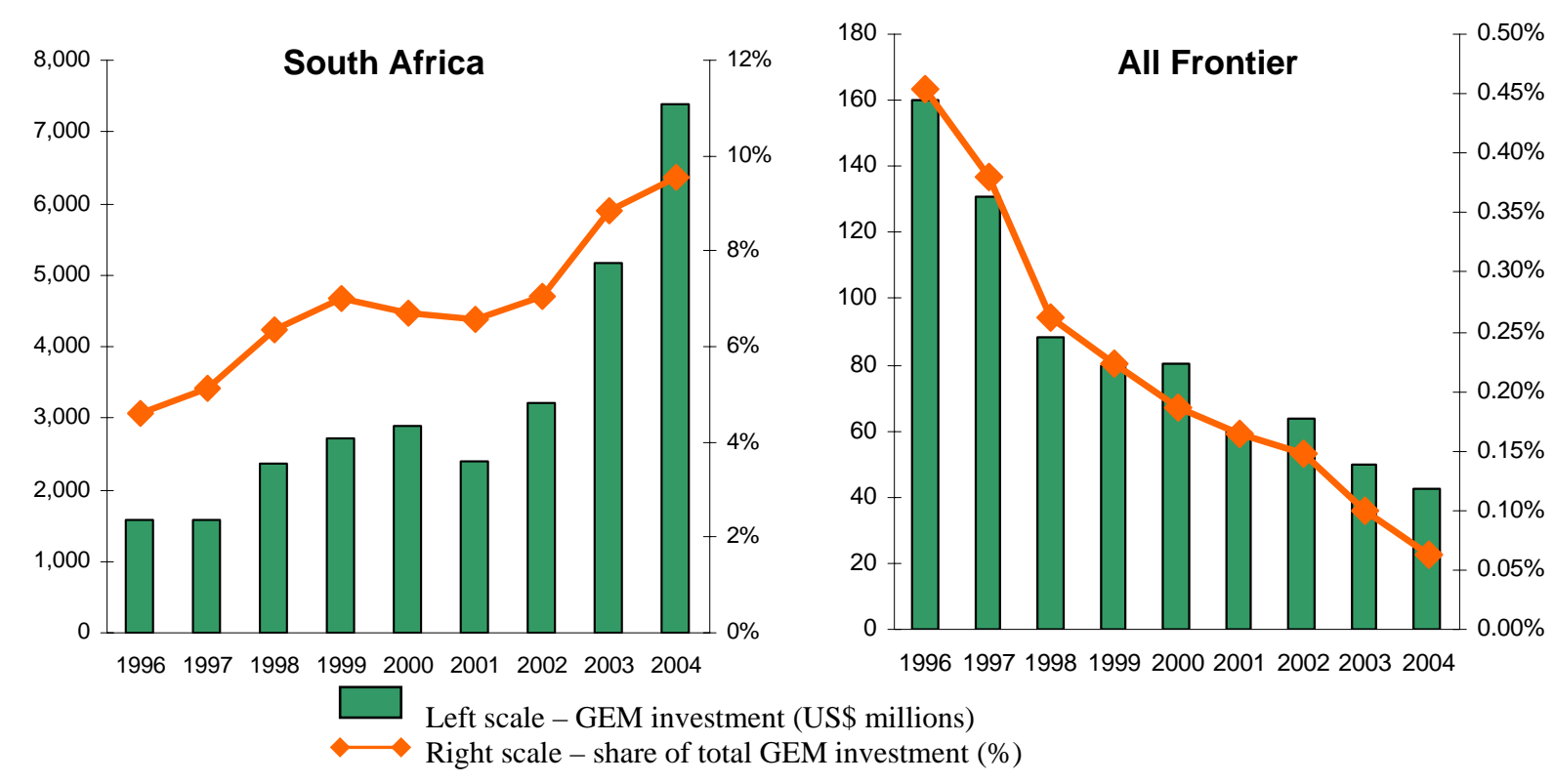

Source: EmergingPortfolio.com Fund Research

The story for frontier markets is almost a mirror opposite. The eleven other African markets attracted a combined $0.03 \%$ of the total assets. Zimbabwe was the largest single recipient with three funds holding \$9 million worth of assets. Mauritius was held by two funds for a total of \$3 million. Kenya (\$1 million), Ghana (\$4 million), Nigeria (\$5 million) and Botswana (\$5 million) were held by only a single fund each. No GEM fund held any assets in Cote d'Ivoire, Namibia, Malawi or Zambia at end-2005 (Annex B; Table B3).

The trend is also not favorable, with frontier holding falling both in absolute and relative terms. From a high of $\$ 238$ million at end-1996, assets held in African frontier markers are now worth only $\$ 28$ million. As a share of the global total, investment to the rest of the continent has fallen from $0.56 \%$ to $0.03 \%$ (Figure 3 for moving 3-year averages). While extremely small sample size suggests caution about over-interpreting trends from these figures, they are nonetheless in stark contrast to the trends seen in the South African numbers.

The levels of GEM investment in sub-Saharan Africa may be extremely low, but, given the characteristics of these frontier markets, are they out of line with global trends? The data suggests a fairly emphatic 'no.' A series of simple correlations indicate that African markets receive the level of investment from GEM funds wholly consistent with their size and liquidity. To show this, we plot the share of total GEM investment against market capitalization, value traded, and GDP. ${ }^{12}$ All tell much the same story. For example, GEM fund allocation to any

\footnotetext{
${ }^{12}$ See Annex A for pairwise correlations for these different indicators.
} 
particular country appears to remain near zero until a market reaches a certain threshold followed by a sharp increase in the share of total investment. Figure 4 suggests that to get on the radar of GEM fund managers requires a minimum threshold of about $\$ 50$ billion in total market capitalization and/or total annual value traded of about $\$ 10$ billion.

Figure 4: Share of Total GEM investment (Dec 2005)
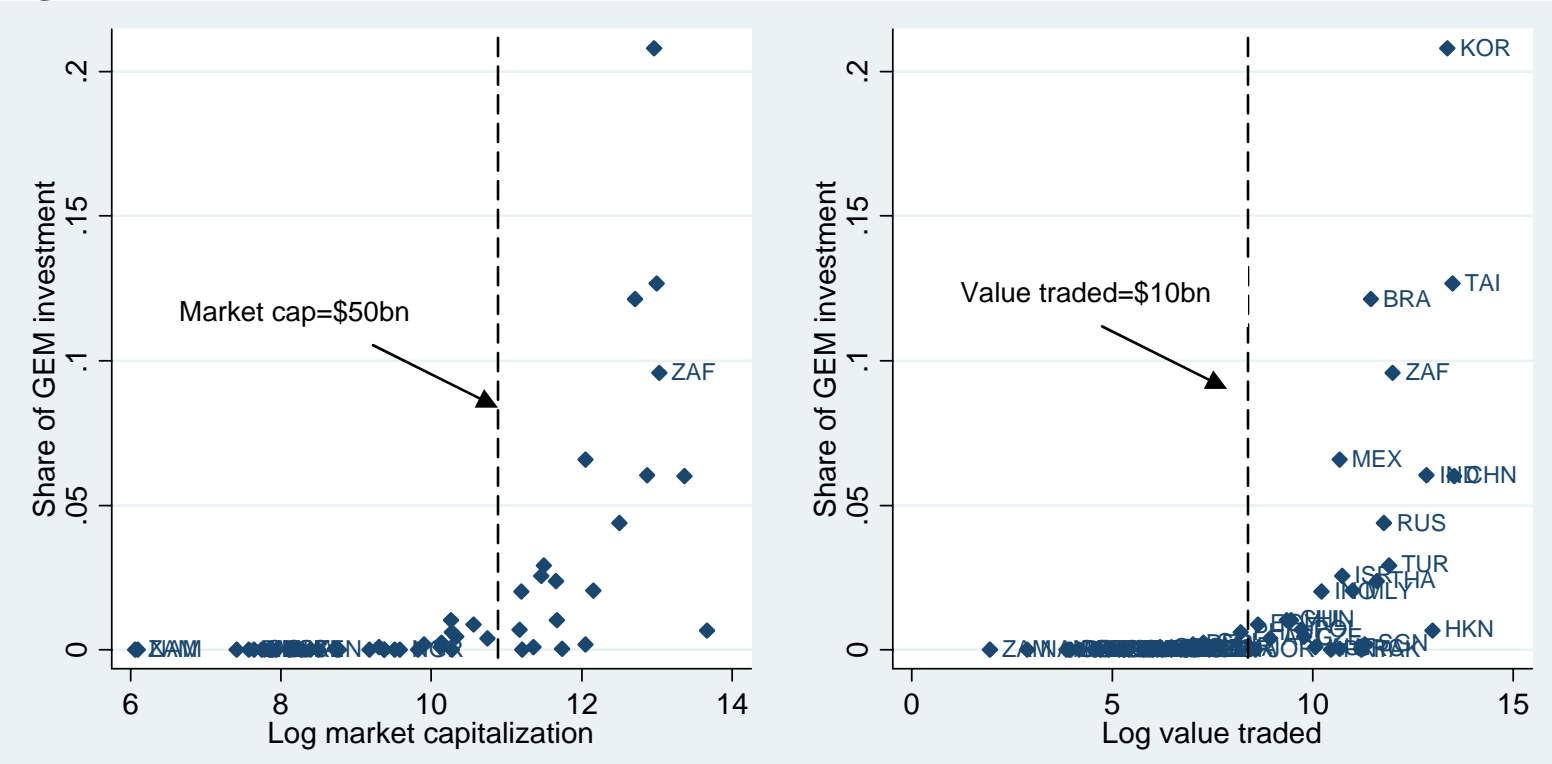

Sources: EmergingPortfolio.com Fund Research and Standard \& Poor’s (2005).

In the left graph of Figure 4, which plots the share of total GEM investment against market capitalization (African markets are labeled), the 20 countries with market capitalization above $\$ 50$ billion receive $96 \%$ of GEM investment. The other 39 countries below this level together receive just $4 \%$ and none individually receives more than $1 \%$ in 2005 . The right graph is nearly identical, with a value traded threshold of about $\$ 10$ billion. All of the African markets, except for South Africa, are far below these thresholds-thus their exclusion from GEM attention is not necessarily a surprise, but perhaps is instead to be fully expected.

The conclusion remains the same if we use different measures of GEM fund investment. As market capitalization and value traded rise, so does GEM investment (Figure 5). ${ }^{13}$

\footnotetext{
${ }^{13}$ Though not pictured, the linear relationship is similar for log GDP.
} 
Figure 5: Value of GEM investment (Dec 2005)
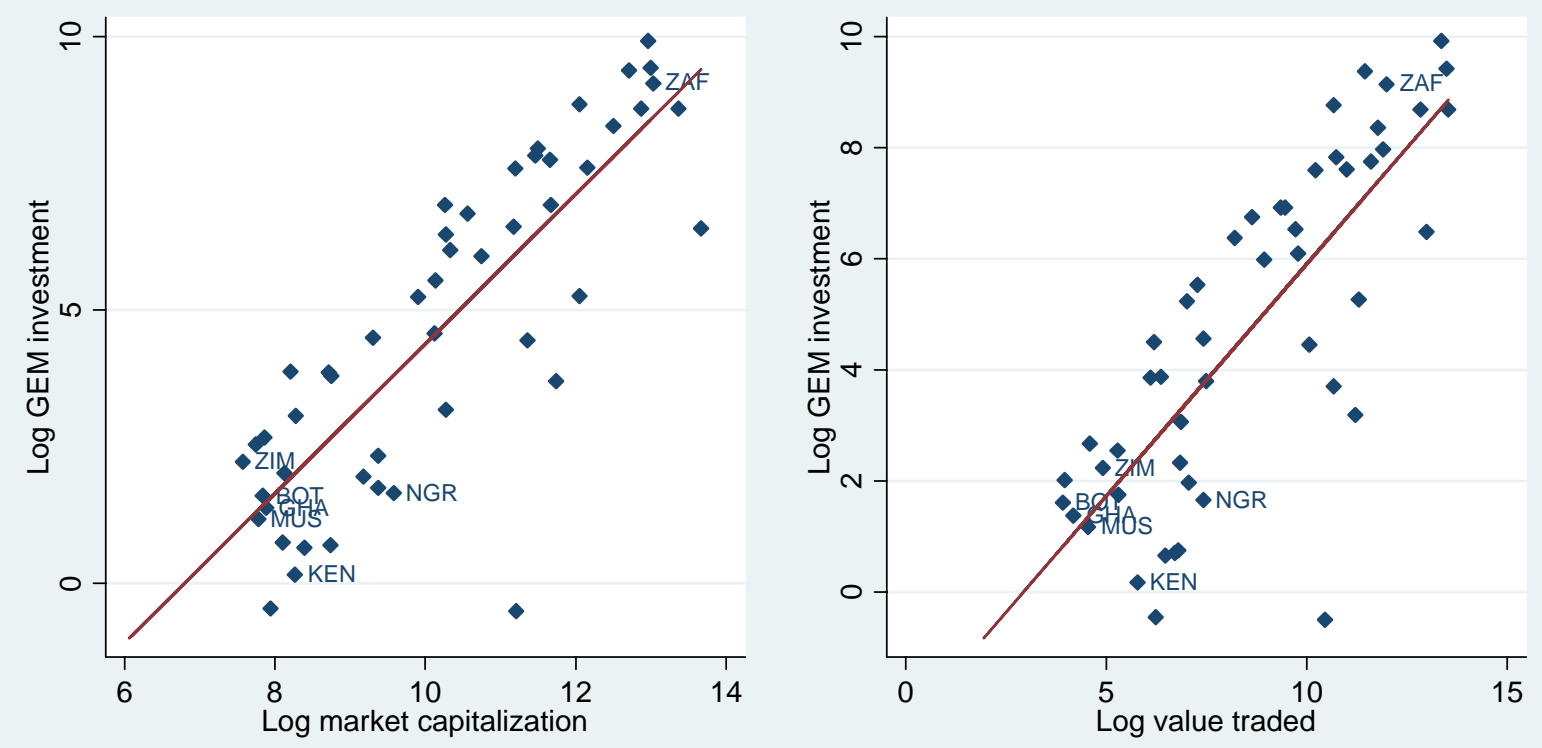

Sources: EmergingPortfolio.com Fund Research and Standard \& Poor’s (2005).

The story is also the same when we observe the relationship between market size and liquidity with the number of GEM funds investing in any particular market (Figure 6). The data appears to show fund managers lumping countries into one of three groups, highly correlated with market size: The first group is those with less than $\$ 20$ billion in market capitalization; fewer than one in ten funds in our sample invested at all in these countries. A second group of middle-sized markets (roughly $\$ 20-150$ billion cap) received more attention from a greater number of funds. A third group of mature emerging markets, countries with over $\$ 150$ billion in market capitalization receive investments by nearly every fund. (A fourth group, in the lower right corner, are countries such as Portugal or Greece which were once considered emerging markets, but have outgrown the asset class and are no longer typically considered emerging markets.) A similar picture is seen in the relationship between the number of funds investing in a market and the value traded on the relevant exchange. Markets cluster in groups, with thresholds at roughly \$1-2 billion traded per year to move out of the bottom group and \$75-100 billion to join the top group. ${ }^{14}$

\footnotetext{
${ }^{14}$ We test to see if Africa is "off the trendline” by carrying out simple regressions of log (share of investment) regressed on log (value traded) and log (market capitalization) and an Africa dummy set to 1 if the country is in Africa. We ran several variations on this specification-in no case was the Africa dummy significant.
} 
Figure 6: Share of GEM funds (Dec 2005)
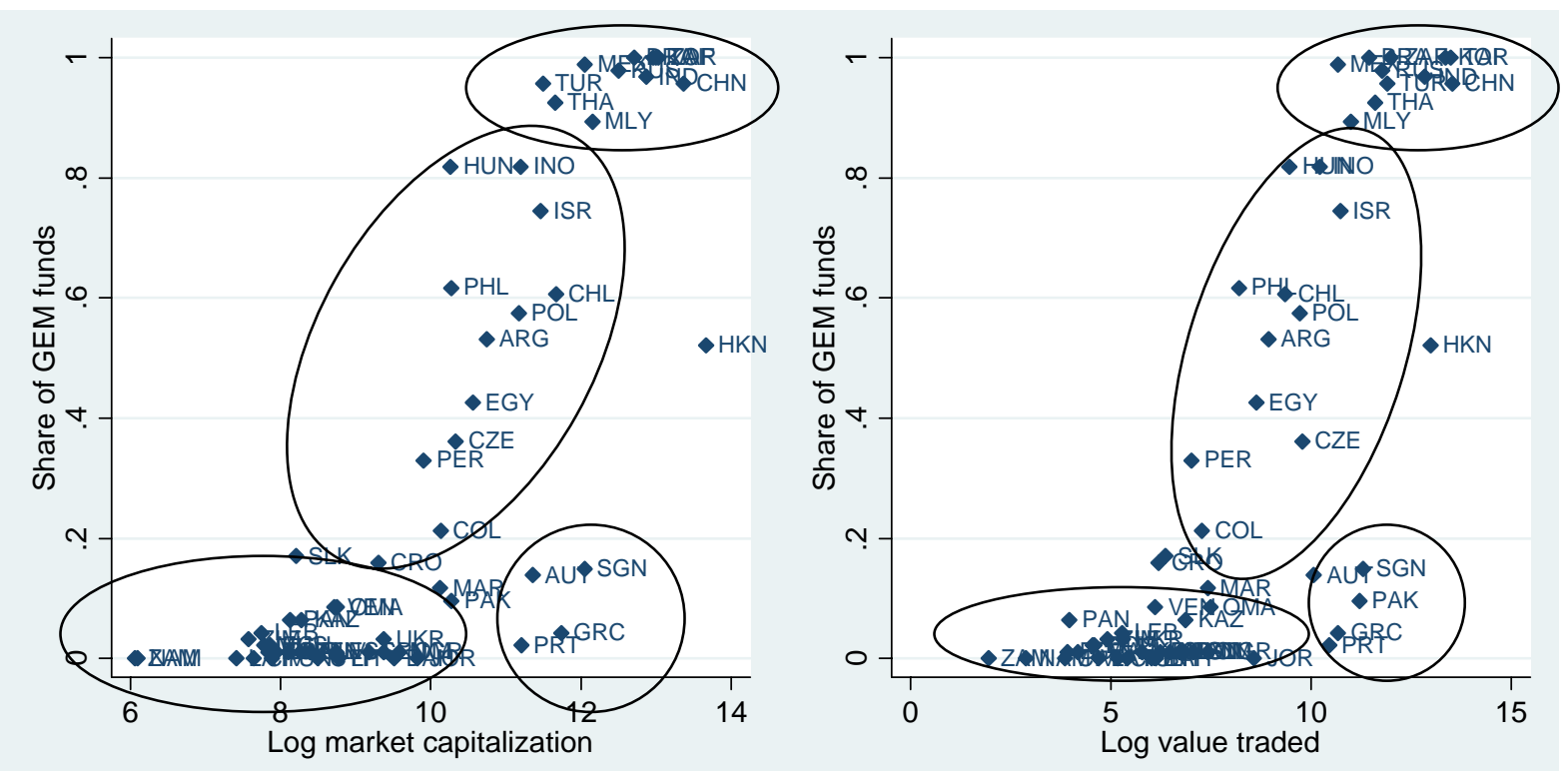

Sources: EmergingPortfolio.com Fund Research and Standard \& Poor's (2005).

Our conclusion from these figures is that African markets are not treated much differently from other countries, and that they may simply be too small to command much attention from GEM fund managers. Combining this cross country data with the information cited above about available blocks of African shares, and the general minimum trade sizes of many funds (which typically exceed the normally available blocks), the picture becomes clearer. ${ }^{15}$

The quantitative analysis described above is consistent with qualitative evidence provided by interviews with fund managers and market markers. Michael Schwabe, former manager of Morgan Stanley's Africa Fund, called the lack of liquidity the major deterrent to investors in the region (Emergingportfolio.com 1999). A Financial Times profile of the Ghana exchange noted that when the Simba Fund was trying liquidate its assets, it had trouble exiting the Ghana market because of a lack of buyers at any price (Kibazo 2000). Even where international fund managers may have an initial interest in a frontier market, the realities of limited market size and liquidity, keep them out.

\footnotetext{
${ }^{15}$ Anecdotal evidence suggests that many funds target a minimum trade size of at least $\$ 1$ million, with some of the larger funds seeking $\$ 5$ million or greater sized blocks. A sample of the individual holdings of several funds (which is not available through the EPFR database) suggests that very few funds hold blocks smaller than $\$ 500,000$ and those above the average GEM size fund (about \$1 billion) tend not to have holdings smaller than \$1 million for any single share.
} 


\section{Africa's small market size}

Our conclusion is that there is not an "Africa effect" per se but rather a set of problems combining size and level of GDP, which is hindering investment. Countries can rely on one or the other to cross the threshold—-for example, India is relatively poor but its larger size generates enough enterprises that generate investor interest. There are also examples of relatively small countries which have become rich enough to generate enough firms to attract the kinds of investments we are discussing in this paper. But for Africa, level of GDP and size of market size are significant constraints, and this in turn may be determined by various underlying factors, including a poor investment climate.

There is a large literature on the constraints faced by the private sector which may help to explain the problem of small market size, including the combined obstacles of infrastructure and regulation and political economy factors that have prevented the rise of a sizeable black entrepreneurial class (Eifert, Gelb and Ramachandran, 2005; Ramachandran and Shah, 2007). Despite recent reforms, African firms still suffer from a harsh business climate; one that reduces their productivity to a significant extent when compared to firms in other parts of the world. Data from the World Bank's Investment Climate Surveys show that most firms in the formal private sector in sub-Saharan Africa are very small, of the order of 10-50 employees. They are also particularly disadvantaged when it comes to the supply of infrastructure. ${ }^{16}$ They suffer from burdensome regulations and in some cases, from high levels of corruption as well.

The investment climate survey data show that business losses due to investment climate constraints - power outages, transport failures, and logistics delays — are largely responsible for shortfalls in productivity observed in the data. African firms report substantially higher losses than their counterparts in higher-performing countries, which translates into a corresponding decline in measured productivity. In Kenya for example, losses from power failure amount to $6 \%$ of sales for the median firm, whereas in China, they are only $1 \%$ of sales. In total, "indirect costs" comprising of energy, transport, land, and telecom are less of a relative burden for higherperforming firms. Figure 7 provides a cross-country comparison of firms' cost structures, including labor (wages, benefits), capital (interest, finance charges, machine depreciation), raw materials, and other indirect costs. In strong performers such as China, India, Nicaragua, Bangladesh, Morocco, and Senegal, the combination of energy and indirect costs are 13 to 15 percent of total costs, and around half the level of labor costs. In contrast, this combination in most African countries accounts for 20 to 30 percent of total costs, often dwarfing labor costs.

\footnotetext{
${ }^{16}$ For more detail about these datasets and how the data are collected, see www.enterprisesurveys.org.
} 


\section{Figure 7: Cost Structures, Firm-Level Average by Country}

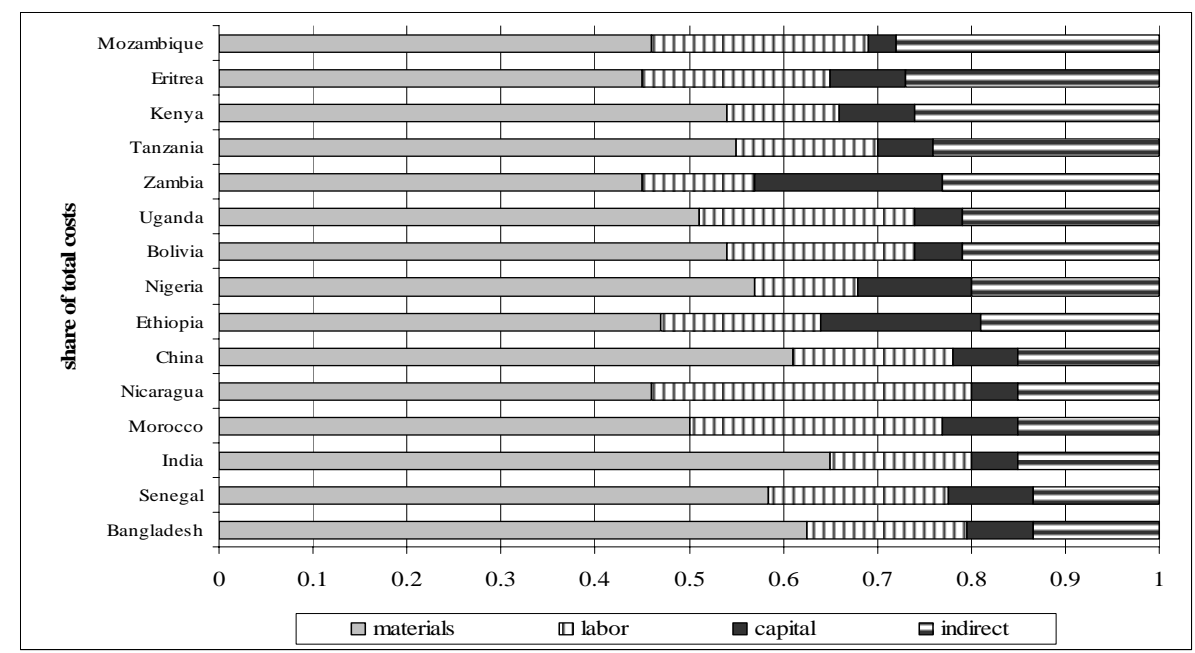

African firms also report substantially higher losses than their counterparts in higher-performing countries, which translate into a corresponding decline in measured productivity. A substantial portion of the variance in measured productivity between China and several African countries (especially Zambia, Ethiopia, Kenya, Nigeria, and Tanzania) can therefore be attributed to infrastructure and logistics-related losses rather than intrinsic capabilities.

How does all of this affect market size? The data suggest that African firms are faced with constraints that prevent them from increasing productivity and expanding their operations. A high cost business environment has reduced the competitiveness of African firms, thereby limiting their ability to grow. It has very likely hampered the entry of new firms and increased the exit of firms. We do not yet know if Africa's investment climate is in line with its per capita GDP or whether it is exceptionally poor; this is an important subject for future work. To explore this question, we will need to look at the investment climate in comparably poor countries outside Africa. 


\section{Conclusion}

Africa has made significant progress in developing its domestic capital markets. Information on African markets is improving, regulatory and financial sector reforms have been implemented, and countries are beginning to adopt modern technologies such as automated trading and central depository systems. South Africa has successfully risen into the ranks of the leading emerging market destinations. However, the rest of the continent remains largely outside the expansion in global financial flows witnessed over the past two decades. Africa's “frontier markets" remain firmly off the radar of international portfolio fund managers, with the exception of a handful of Africa fund managers - and possibly Nigeria whose market capitalization has recently topped \$30bn. This paper suggests, however, that the overall level of GEM investment in African markets is consistent with global trends. Given the size and liquidity constraints that characterize these markets, the amount of attention from equity fund managers seems in line with global norms.

This analysis broadly supports the "market works" view of why Africa does not get more equity investment, but has some substantial implications for strategies to grow these markets and attract new investors. This conclusion suggests that many of the public policy interventions intended to increase equity investment in Africa are unlikely to have a significant impact in the short and medium terms. The implications for Africa and policymakers are threefold. First, for the foreseeable future, foreign fund investment in the frontier markets will be limited largely to those funds with regional specialties. Investment promotion efforts should therefore focus on increasing domestic institutional and individual investment and concentrate foreign efforts on raising the number of regional funds rather than attempting to lure general emerging market funds.

Second, the depth and success of the Johannesburg Stock Exchange need not remain constrained within South Africa's borders. Botswana, Namibia, and others have increased cross-listings-a trend that should continue to be encouraged. While wholesale regionalization of bourses faces significant barriers, there are other cooperative arrangements that would allow frontier markets to benefit more fully from the liquidity and exposure of the JSE (Irving 2005; Okeahalam 2005).

Finally, a long-term strategy for attracting equity investment should concentrate on increasing the supply of available securities_-since demand will come naturally through the market. Increasing supply means tackling the barriers of small market and firm size to encourage the growth of more and larger firms on the continent. Solutions to increasing the size and scope of the African private sector must focus on improving the investment climate, reducing the level of risk and uncertainty, and providing greater means for small, indigenous firms to survive and grow without inducing large distortions. While these issues are far beyond the scope of this paper, it is worth emphasizing that addressing the problem of private sector growth-rather than attempting to fight imagined "market failures"-is a crucial component of any overall plan to increase equity investments in the region. 


\section{References}

Africa Financing Review (1998). “Botswana - Stock market report,” p. 1, November 1.

Barber, Simon (2000). "Politics hover in background as US-based fund sacks boss,” Business Day, November 8.

Bhattacharya, Amar, Peter J. Montiel and Sunil Sharma (1996). "Private Capital Flows to SubSaharan Africa: An Overview of Trends and Determinants,” in Zubair Iqbal and Ravi Kanbur. External Finance for Low Income Countries, Washington: IMF, pp. 207-232.

Borensztein, Eduardo and R. Gaston Gelos (2000). “A Panic-Prone Pack?: The Behavior of Emerging Market Mutual Funds,” IMF Working Paper No. 00/198, Washington: International Monetary Fund.

Caprio, Gerard, Jr. and Asli Demirguc-Kunt (1997). “The Role of Long-Term Finance: Theory and Evidence,” Working Paper No. 1746, Washington: World Bank.

Christy, John (1998). "Bright spots on the Dark Continent,” Forbes, October.

Chuhan, Punam, Stijn Claessens and Nlandu Mamingi (1993). "Equity and Bond Flows to Asia and Latin America,” World Bank Working Paper No. 1160, Washington: World Bank.

Cranston, Stephen (2005). “A Shot in the Dark,” Financial Mail, December 16.

Economist (1997). “African stockmarkets: no joke,” January 11.

Eifert, Ben, Alan Gelb and Vijaya Ramachandran (2005). "Business Environment and Comparative Advantage in Africa: Evidence from the Investment Climate Data,” Working paper 56, Washington: Center for Global Development.

EIU (2001). Business Africa, April 16.

Emergingportfolio.com (1999). "Fund Profile: Morgan Stanley Africa Investment Fund,” September.

Fernandez-Arias, Eduardo (1994). “The New Wave of Private Capital Inflows: Push or Pull?” Policy Research Working Paper No. 1312, Washington: World Bank.

Fernandez-Arias, Eduardo and Peter Montiel (1996). "The Surge in Capital Inflows to Developing Countries: An Analytical Overview.” World Bank Economic Review, Vol. 10, No. 1, pp. 51-77.

Frankel, Jeffrey A. and Chudozie Okongwu (1995). "Liberalized Portfolio Capital Inflows in Emerging Markets: Sterilization, Expectations, and the Incompleteness of Interest Rate Convergence,” NBER Working Paper Series, No. 5156, Cambridge: National Bureau of Economic Research.

Gande, Amar and David Parsley (2004). "The behaviour pattern of foreign equity investors during the financial crises of the late 1990s,” Vanderbilt University.

Gelos, Gaston R. and Shang-Jin Wei (2002). “Transparency and International Investor Behavior,” IMF Working Papers 02/174, Washington: International Monetary Fund. 
Gottschalk, Ricardo and Stephany Griffith-Jones (2003). “The behaviour pattern of foreign equity investors during the financial crises of the late 1990s,” Institute of Development Studies, Brighton: University of Sussex.

Investec (2006). Pan Africa Fund, Q3, 2006 update, Investec Asset Management.

Irving, Jacqueline (2005). Regional Integration of Stock Exchanges in Eastern and Southern Africa: Progress and Prospects,” IMF Working Paper 05/122, Washington: IMF.

Kaminsky, Graciela, Richard Lyons and Sergio Schmukler (2001). "Mutual Fund Investment in Emerging Markets: An Overview,” Policy Research Working Paper No. 2529, Washington: World Bank.

Kenny, Charles and Todd Moss (1998). "Stock Markets in Africa: Emerging Lions or White Elephants?” World Development, Vol. 26, No. 5.

Kibazo, Joel (2000). “Survey-Ghana,” Financial Times, November 29.

King, Robert and Ross Levine (1993). "Finance and Growth: Schumpeter Might be Right," Quarterly Journal of Economics, Vol. 108, No. 3, pp. 717-738.

Lavelle, Kathryn (1999). “International financial Institutions and Emerging Capital Markets in Africa,” Review of International Political Economy, Vol. 6, No. 2, pp. 200-224.

Levine, Ross (1996). "Financial Development and Economic Growth: Views and Agenda," Policy Research Working Paper No. 1678, Washington: World Bank.

Levine, Ross and Sara Zervos (1996). "Stock Market Development and Long Run Growth," World Bank Economic Review, Vol. 10, No. 2.

McKinnon, Ronald (1973). Money and Capital in Economic Development, Washington: The Brookings Institution.

Morgan Stanley (2001). “Morgan Stanley Africa Investment Fund Inc, 2001 Annual Report.”

Moss, Todd, (2003). Adventure Capitalism: Globalization and the political economy of stock markets in Africa, New York: Palgrave MacMillan.

Murray, Sarah (2002). "Development social priorities in new markets,” Financial Times, December 19.

Ndikumana, Leonce (2001). “Financial Markets and Economic Development in Africa,” PERI Working Paper 17, Political Economy Research Institute, Amherst: University of Massachusetts.

Offerdal, Erik (1996). “The Response of Investment and Growth to Adjustment Policies,” Finance \& Development, June, pp. 18-20.

Okeahalam, Charles (2005). "Strategic Alliances and Mergers of Financial Exchanges: The Case of the SADC,” Journal of Southern African Studies, Vol. 31, No. 1.

Ramachandran, Vijaya and Manju Kedia Shah (2007). "Why Are There So Few Black-Owned Businesses in Africa?,” CGD Working Paper 104.

Ramachandran, Vijaya, Manju Kedia Shah, and Gaiv Tata (2006). "Does Influence Peddling Impact Industrial Competition? Evidence from the Africa Investment Climate Surveys,” World Bank, forthcoming. 
Robinson, Joan (1952). The Rate of Interest and Other Essays, London: Macmillan.

Samuel, Cherian (1996). "Stock Market and Investment: The Governance Role of the Market," Working Paper No. 1578, Washington: World Bank.

Schneider, Friedrich and Robert Klinglmair (2004). "Shadow Economies around the World: What do we know?” WP 2004-03, Linz: Center for Research in Economics, Management and the Arts.

Schumpeter, Joseph (1934). The Theory of Economic Development, Cambridge: Harvard University Press.

Serres, Chris (2001). "Business pals' venture in Africa ends in suit, split," The News and Observer, March 11.

Shaw, Edward (1973). Financial Deepening in Economic Development, New York: Oxford University Press.

Siddiqi, Moin (1997). "Although Africa is still relatively small as an emerging market, the potential for growth is substantial," African Business, November 3.

Simba Fund Limited (2000). "Preliminary Statement of Half-Yearly Results in respect of the Company's Interim Accounting Period from $1^{\text {st }}$ January to $30^{\text {th }}$ June 2000.”

Sisler, Peter (1995). “US group launches Africa money fund,” United Press International, April 12.

Sloan Financial Group, Inc., et al. v. Justin F. Beckett (2003). North Carolina Reports and North Carolina Court of Appeals Reports.

Standard \& Poor's (2006). Data retrieved October 2006 from http://www.funds-sp.com.

Tangri, Roger (2000). The Politics of Patronage in Africa: Parastatals, Privatization and Private Enterprise in Africa, Trenton: Africa World Press.

Umoren, Rose (1995). “First Pan-African Mutual Fund Flounders,” Inter Press Service, September 27.

World Bank (2006). Doing Business 2007: How to Reform, Washington.

Xaba, Jantjie, Pat Horn and Shirin Motala (2002). "The Informal Sector in Sub-Saharan Africa," Employment Sector 2002/10 Working Paper on the Informal Economy, Geneva: International Labor Office. 


\section{Annex A}

Measures of GEM fund investment have strong and positive relationships with individual market characteristics. Table A1 gives the simple pairwise correlations of three variables measuring GEM investment (log GEM investment, share of total GEM investment, and share of total funds investing in a market) and three measures of market size and liquidity (log market capitalization, log value traded, and log of host economy GDP).

Table A1: Pairwise correlations

\begin{tabular}{|l|rrrrrr|}
\hline & log_inv & share_ $\mathbf{v}$ & share_ s & log_cap & log_tr d & log_gdp \\
\hline log_inv & 1 & & & & & \\
Share_inv & 0.6715 & 1 & & & & \\
share_funds & 0.9308 & 0.7173 & 1 & & & \\
log_cap & 0.8286 & 0.6027 & 0.8072 & 1 & 1 & \\
log_traded & 0.7861 & 0.6024 & 0.7962 & 0.9582 & 1 \\
log_gdp & 0.7892 & 0.5775 & 0.7752 & 0.8908 & 0.8906 & 1 \\
\hline
\end{tabular}




\section{Annex B}

Table B1: GEM Fund assets by region, end-2005

\begin{tabular}{|lrr|}
\hline Region & $\begin{array}{c}\text { GEM } \\
\text { investment } \\
\text { (US\$ } \mathbf{~ m n})\end{array}$ & $\begin{array}{c}\text { Share of } \\
\text { total }\end{array}$ \\
\hline Asia & 52,533 & $55 \%$ \\
Latin America/Caribbean & 20,266 & $21 \%$ \\
Emerging Europe & 9,571 & $10 \%$ \\
Sub-Saharan Africa & $\mathbf{9 , 4 3 6}$ & $\mathbf{1 0 \%}$ \\
$\quad$ of which South Africa & $\mathbf{9 , 4 0 9}$ & $\mathbf{1 0 \%}$ \\
Middle East/North Africa & 3,528 & $4 \%$ \\
\hline Total & $\mathbf{9 5 , 3 3 4}$ & $\mathbf{1 0 0 \%}$ \\
\hline
\end{tabular}

Source: EPFR

Table B2: Country allocation of GEM Funds, end-2005

\begin{tabular}{|clrr|}
\hline Rank & Country & $\begin{array}{r}\text { GEM investment } \\
\text { (US\$ mn) }\end{array}$ & Share of total \\
\hline 1 & Korea & 20,410 & $21 \%$ \\
2 & Taiwan & 12,430 & $13 \%$ \\
3 & Brazil & 11,903 & $12 \%$ \\
$\mathbf{4}$ & South Africa & $\mathbf{9 , 4 0 9}$ & $\mathbf{1 0 \%}$ \\
5 & Mexico & 6,449 & $7 \%$ \\
6 & India & 5,918 & $6 \%$ \\
7 & China & 5,911 & $6 \%$ \\
8 & Russia & 4,297 & $4 \%$ \\
9 & Turkey & 2,871 & $3 \%$ \\
10 & Israel & 2,515 & $3 \%$ \\
\hline
\end{tabular}

Source: EPFR

Table B3. GEM holdings in SSA countries (December 2005)

\begin{tabular}{|c|c|c|c|c|c|}
\hline Country & $\begin{array}{c}\text { \# of GEM funds with } \\
\text { investments (out of } 94 \\
\text { tracked) }\end{array}$ & $\begin{array}{l}\text { Est. value of all } \\
\text { GEM holdings } \\
\text { (US\$ mn) }\end{array}$ & $\begin{array}{c}\text { Share of total } \\
\text { GEM investment } \\
(\%)\end{array}$ & $\begin{array}{c}\text { Avg. Share } \\
\text { allocation -- all } \\
\text { GEM funds (\%) } \\
\end{array}$ & $\begin{array}{l}\text { Largest share } \\
\text { allocation (\%) }\end{array}$ \\
\hline Botswana & 1 & 5.0 & 0.01 & 0.01 & 0.80 \\
\hline Cote d'Ivoire & 0 & 0.0 & 0.00 & 0.00 & 0.00 \\
\hline Ghana & 1 & 4.0 & 0.00 & 0.01 & 0.64 \\
\hline Kenya & 1 & 1.2 & 0.00 & 0.00 & 0.19 \\
\hline Malawi & 0 & 0.0 & 0.00 & 0.00 & 0.00 \\
\hline Mauritius & 2 & 3.2 & 0.00 & 0.01 & 0.52 \\
\hline Namibia & 0 & 0.0 & 0.00 & 0.00 & 0.00 \\
\hline Nigeria & 1 & 5.2 & 0.01 & 0.01 & 0.84 \\
\hline South Africa & 94 & $9,408.5$ & 9.58 & 9.36 & 14.34 \\
\hline Zambia & 0 & 0.0 & 0.00 & 0.00 & 0.00 \\
\hline Zimbabwe & 3 & 9.3 & 0.01 & 0.00 & 0.16 \\
\hline
\end{tabular}

Source: Author calculations based on EPFR 